

Berdasarkan SK Dirjen Dikti Nomor: 66b/DIKTI/Kep/2011, tanggal 9 September 2011 tentang Hasil Akreditasi Terbitan Berkala Ilmiah, LITERA dinyatakan sebagai Terbitan Berkala Ilmiah Terakreditasi, periode Agustus 2011 sampai dengan Agustus 2016 




Jurnal Penelitian Bahasa, Sastra, dan Pengajarannya

Volume 12, Nomor 1, April 2013

* Fenomena Perdagangan Perempuan dalam Fiksi Jawa Modern.

Darni 


\title{
FENOMENA PERDAGANGAN PEREMPUAN DALAM FIKSI JAWA MODERN
}

\author{
Darni \\ FBS Universitas Negeri Surabaya \\ email: darniunesa@gmail.com
}

\begin{abstract}
Abstrak
Penelitian in bertujuan menggambarkan praktik perdagangan wanita dalam fiksi Jawa modern.Gejala ini dikaji berdasarkan ideologi dan penyebabnya menggunakan teori New Historicism. Hasil penelitian menunjukkan bahwa perdagangan perempuan yang dialami para tokoh dalam semua cerita sama. Mereka ditipu oleh mucikari dan dijual sebagai pelacur di Indonesia dan di luar negri.Ada tiga penyebab mengapa terjadi perdagangan wanita, yaitu pandangan yang merendahkan perempuan, ketergantungan perempuan, dan kemiskinan dan rendahnya pendidikan perempuan. Teks tentang perdagangan wanita lebih mendukung feminisme.Perempuan sebagai korban dapat memperoleh kebebasan dan kemandirian.Ideologi feminisme juga didukung oleh kaum laki-laki.Tokoh lakilaki membantu tokoh perempuan untuk lepas dari perdagangan perempuan dengan menerimanya sebagai pasangan.
\end{abstract}

Kata kunci: mucikari, pelacur, pandangan yang merendahkan perempuan, feminisme

\section{WOMAN TRAFFICKING PHENOMENA IN MODERN JAVANESE FICTION}

\begin{abstract}
This study aims to describe woman trafficking practice in modern Javanese fiction. Woman trafficking was analyzed based on the ideology and causes using New Historicism theory. The findings show that woman trafficking experienced by the characters in all of the stories is the same. They are deceived by procurers and sold as prostitutes in Indonesia and abroad. There are three causes of womantrafficking, i.e. a view looking down on women, woman dependency, and women's poverty and low education. The stories of woman trafficking support feminism more. Women as victims of woman trafficking can get freedom and autonomy. Feminism ideology is also supported by men. The male characters help the female characters release themselves from woman trafficking by accepting them as their partners.
\end{abstract}

Keywords: procurer, prostitute, view looking down on women, feminism

\section{PENDAHULUAN}

Perempuan dipandang berbeda dengan laki-laki. Di belahan bumi bagian Barat apalagi Timur, perempuan mengalami diskriminasi. Perempuan dianggap lebih rendah dibanding laki-laki. Bahkan ada pandangan hitam putih antara lakilaki dan perempuan. Laki-laki dianggap sebagai makhluk yang perkasa dan memiliki kedudukan yang lebih tinggi. Se- dangkan perempuan dianggap sebagai makhluk yang lemah dan tidak berdaya, sehingga berkedudukan lebih rendah. Dalam masyarakat Jawa pandangan tersebut tertuang dalam ungkapan-ungkapan seperti: wanita iku panggonane neng mburi, wanita iku ibarate swarga nunut neraka katut. Perempuan selalu di belakang, di dapur dan tidak dipertimbangkan. Perempuan juga tidak memiliki peran penting dalam 
masyarakat. Perempuan bisa hidup enak atau tidak bergantung kepada laki-laki.

Pandangan rendah terhadap perempuan tersebut menurut Herkiswono (2000:76) disebabkan oleh adanya sistem patriarkhi yang menguasai tatanan sosial masyarakat. Laki-laki yang bertahta sebagai pemimpin memiliki kekuasaan atas perempuan. Kekuasaan laki-laki memberi peluang kepada laki-laki untuk menindas perempuan. Pengamatan Hassan (2004:x) menunjukkan bahwa patriarkhi menjadi sumber kesewenang-wenangan laki-laki terhadap perempuan.

Pandangan rendah terhadap perempuan tampak pada praktik-praktik sosial kekerasan terhadap perempuan, seperti perdagangan perempuan, pelecehan seksual, pencabulan, pemerkosaan, perselingkuhan, dan penelantaran. Perempuan diperlakukan sebagai objek seks, yakni diperdagangkan, dilecehkan, dicabuli, diperkosa, ditinggal selingkuh, dan dihamili lalu ditelantarkan.

Perdagangan perempuan atau trafficking terjadi apabila bisnis perdagangan tersebut dilakukan dengan paksaan dan penipuan. Perempuan tidak mengetahui dan tidak menyadari pekerjaan yang akan dijalani sejak awal. Para perempuan dibujuk akan diberi pekerjaan yang halal, namun pada kenyataannya perempuan ditipu dan dijual sebagai perempuan penghibur.

Penelitian yang dilakukan oleh Wahyuningsih dkk (2003:13) menunjukkan secara umum ada13 unsur dari tindakan perdagangan orang, yaitu: tindakan, pemindahan orang, di dalam negara, atau melintasi perbatasan wilayah negara, adanya tindakan atau ancaman kekerasan, penipuan, lilitan hutang, penyalahgunaan kekuasaan, pekerjaan yang tidak dikehendaki, perbudakan, pelacuran, pemerasan seksual, dan penghilangan organ tubuh.

Penelitian Wismayanti (2010:63) menunjukkan bahwa ada lima macam perantara yang dilewati korban perdagangan perempuan, yakni kerabat atau keluarga, pacar, sahabat atau teman dekat baik laki-laki atau perempuan, orang lain (tukang becak, ojek, calo), dan mucikari. Mereka membujuk korban dengan rayuan akan dipekerjakan pada perusahaan atau rumah makan dengan persyaratan yang mudah. Adanya ketertarikan korban pada calo perdagangan orang karena kemiskinan dan keterbelakangan. Kedua hal tersebut mempermudah calo mengintip korban untuk dijadikan sasaran.

Perdagangan perempuan tersebut membentuk tiga cerita fiksi Jawa modern, yakni dua novel dan satu cerita bersambung. Ketiga cerita tersebut semuanya ditulis oleh pengarang laki-laki. Ketiganya terbit setelah tahun 2004, saat UU KDRT lahir. Ketiga cerita tersebut yaitu Astirin Mbalela karya Suparto Brata terbit tahun 2007, Trah karya Atas S. Danusubroto terbit tahun 2008 dan Mecaki Lurung kang Ilang karya Ismoe Riyanto terbit tahun 2008.

Ada kaitan erat antara sastra dan konteksnya. Menurut Darma (2007:136), pada hakikatnya sastra tidak lepas dari kondisi sosial. Dalam kalimat yang berbeda, juga dinyatakan bahwa sastra berkaitan erat dengan masyarakatnya. Karya sastra tidak lahir dari kekosongan, melainkan dilatari oleh sosio budaya masyarakat yang menghasilkannya (Damono, 1979. Jauh sebelumnya juga telah dikemukakan oleh Swingewood (1972:19) bahwa karya sastra mencerminkan nilai-nilai dan norma-norma masyarakat. Ditambahkan oleh Wellek (2001:109) bahwa karya sastra menyajikan kehidupan, yang sebagian besar terdiri dari kenyataan sosial. Bahkan menurut Tyson (1999:180), ada hubungan timbal balik antara keduanya. Sastra dan masyarakat saling mempengaruhi atau saling membentuk. Sastra dibentuk oleh masyarakatnya, demikian pula sebaliknya. Sastra juga dapat membentuk masyarakat. 
Berdasarkan latar belakang di atas, tujuan penelitian ini ada tiga. Pertama mendeskripsikan praktik sosial yang membentuk tema perdagangan perempuan dalam fiksi Jawa modern. Kedua, menemukan penyebab perdagangan perempuan dalam fiksi Jawa modern. Ketiga, menemukan ideologi yang didukung oleh teks fiksi Jawa modern bertema perdagangan perempuan.

Eksistensi perempuan dalam masyarakat Jawa yang ikut mengonstruksi sastra Jawa modern merupakan kelompok masyarakat yang terpinggirkan. Untuk mengaji perempuan dan hal-hal yang terjadi terhadap perempuan, termasuk kekerasan dalam bentuk perdagangan perempuan, diperlukan kajian yang memberi perhatian kepada perempuan. New Historicism dipilih sebagai teori dalam penelitian ini. Menurut Tyson (1999:276), New Historicism merupakan salah satu teori yang memberikan perhatian kepada kelompok masyarakat yang terpinggirkan, termasuk perempuan.

Asumsi dasar New Historicism seperti yang diungkapkan oleh Greenblatt (2005:5) adalah adanya pengaruh timbal balik antara manusia dan kebudayaannya. Manusia dibentuk dan ikut membentuk kebudayaan tempat mereka hidup. Didukung pula oleh Tyson (1999:286) bahwa hubungan antara individu dan masyarakat saling konstitutif.Tidak ada semangat zaman monolitik. Wacana selalu dalam keadaan perubahan terus menerus dan tumpang tindih. Oleh karena itu New Historicism memandang laporan sejarah sebagai naratif, sebagai cerita, karena biasnya tidak bisa dihindari. Ditambahkan oleh Con (1989:374) bahwa sejarah dan sastra merupakan produk bahasa yang memiliki kesamaan sebagai sebuah wacana narasi. Begitu juga yang disampaikan oleh Budianta (2006:3) bahwa kenyataan sejarah tidak tunggal dan absolut, melainkan terdiri dari bermacam-macam versi yang penuh kontradiksi, keterputusan, dan pluralitas.
Pandangan pluralitas terhadap sejarah tersebut oleh Branningan (1999:147) dijelaskan lebih lanjut bahwa dalam penelaahan sejarah dalam karya sastra, tugas utamanya tidak untuk menemukan apa yang teks cerminkan atau tidak. Ahli tersebut memandang sastra merupakan kendaraan bagi representasi sejarah. Dengan demikian teks sastra menunjukkan proses-proses dan ketegangan-ketegangan yang terjadi karena adanya perubahan sejarah. Ditambahkan oleh Myers (1989), dalam kritik New Historicism fokusnya pada bagaimana teks sastra berfungsi dengan sendirinya sebagai wacana sejarah yang berinteraksi dengan wacana sejarah lainnya. Wacana berhubungan dengan waktu dan tempat teks diatur, waktu teks diterbitkan, atau dalam sejarah penerimaan teks. Namun, ideologilah yang dipentingkan, bukan sejarah. Jika ideologi bukan merupakan hal yang penting dalam sejarah, maka tidak akan ada suatu hubungan sejarah. Karya sastra adalah agen ideologi.

New Historicism memiliki fokus pada naratif sejarah kelompok-kelompok yang terpinggirkan, seperti perempuan, warna kulit, kaum miskin, kelas pekerja, pria gay, lesbian, dan narapidana. Ditambahkan oleh Budianta (2006:3) bahwa New Historicism tidak menerima begitu saja perbedaan antara budaya tinggi dan rendah. New Historicism justru ingin menunjukkan keterkaitan antara berbagai ragam budaya tinggi dan rendah, sastra dan non sastra saling terkait dengan persoalan-persoalan pada zamannya. Dengan pandangan tersebut, New Historicism telah meruntuhkan aksioma yang mendasari New Criticism, bahwa sastra populer biasanya bersifat konformis, mendukung nilai-nilai dominan yang ada, sedangkan sastra tinggi menentang dan bersikap kritis terhadap tatanan sosial, politik, dan ekonomi.

Di samping memberi perhatian pada kelompok orang yang terpinggirkan, menurut Greenblatt (2000:21) New Historicism juga melibatkan apa yang disebut 
'thick description', deskripsi mendalam. Istilah tersebut dilahirkan oleh seorang ahli antropologi, Clifford Geertz. Diskripsi mendalam berusaha tidak sekedar mencari fakta-fakta, melainkan mencari makna yang kompleks dalam kode budaya yang melandasinya.Dalam bidang sastra, Myers (1989) mencatat empat asumsi New Historicism. Pertama, karya sastra bernilai sejarah, bukan sekedar catatan tentang pikiran seseorang. Karya sastra merupakan bentuk sosial budaya dan untuk memahaminya harus dikaitkan dengan sosio budaya yang menghasilkannya. Kedua, karya sastra merupakan pandangan tertentu terhadap sejarah. Ketiga, seperti halnya karya sastra, manusia, termasuk ahli sejarah dan kritikus juga mengalami bentuk tekanan sosial politik. Keempat, akibatnya ahli sejarah atau kritikus sastra terjebak pada kesejarahannya sendiri. Tak seorangpun yang mampu bangkit dari strukur sosialnya sendiri.

Melalui New Historicism,seperti yang dinyatakan oleh Greenblatt (2000:168-9) dapat dilihat hubungan teks dengan konteksnya yang meliputi: praktik sosial yang dikukuhkan teks, pemahaman sosial yang mendasari teks, kebebasan berpikir yang terbayang dalam teks, dan struktur sosial yang lebih luas atau ideologi yang disanjung atau dipersalahkan oleh teks.Tidak semua permasalahan tersebut dibahas, melainkan permasalahan yang mengarahkan pada konteks yang membentuk sastra Jawa modern.

\section{METODE}

Penelitian ini berada pada bidang ilmu sastra. Penelitian pada bidang ilmu sastra pada umumnya menggunakan model penelitian kualitatif deskriptif. Sunarto (2001:135) mengemukakan bahwa penelitian kualitatif bertujuan untuk mendeskripsikan dan menganalisis fenomena, peristiwa, aktivitas sosial, sikap, kepercayaan, persepsi, pemikiran orang secara individual maupun kelompok.
Sumber data primer penelitian ini adalah cerita bersambung dan novel yang terbit tahun 2005-2010 yang bertema perdagangan perempuan. Pemilihan tahun terbit setelah tahun 2004 dikaitkan dengan sejarah munculnya Undang-Undang Kekerasan Dalam Rumah Tangga(UU KDRT) pada tahun 2004. Dari kurun waktu tersebut, ditemukan tiga cerita yang bertema perdagangan perempuan. Ketiga cerita tersebut adalah: Novel Astirin Mbalela (Brata, 2007), novel Trah (Danusubrata, 2008) dan cerita bersambung Mecaki Lurung kang Ilang (Rianto, 2008). Sumber data sekunder berasal dari konteks, yakni sejarah praktik sosial perdagangan perempuan, patriarkhi, dan feminisme. Data utama dalam penelitian kualitatif adalah kata-kata dan tindakan (Sunarto, 2001:140). Kedua data tersebut menjadi data utama dalam penelitian ini. Kata-kata dan tindakan yang dimaksud adalah kata-kata dan tindakan yang dilakukan oleh para tokoh fiksi Jawa modern mengenai praktik sosial perdagangan perempuan, penyebab, dan ideologi yang didukung.

Metode yang digunakan dalam penelitian sastra memiliki tiga sifat, yakni deskriptif, analitis, dan komparatif (Aminuddin, 1990:120). Ketiga metode disebut digunakan dalam penelitian ini. Di samping memberi penjelasan melalui deskripsi dan analisis secara sistematis dari fakta sasaran kajian yang disusun berdasarkan pendekatan, teori, dan cara kerja yang sudah ditetapkan, penelitian ini juga melakukan komparasi guna meng-hubungkan antara teks dengan konteks sejarahnya. Namun komparasi dalam penelitian ini bukan merupakan kajian sastra bandingan. Komparasi ini dalam rangka menghubungkan teks fiksi Jawa modern bertema perdagangan perempuan dengan konteks sosio budaya, nilai, dan lembaga yang ikut membentuk teks. Komparasi juga digunakan untuk membandingkan karya satu dengan yang 
lain dalam rangka menemukan ideologi yang lebih didukung oleh teks.

Analisis data dalam penelitian ini dimulai dengan analisis deskriptif. Menurut Sunarto (2001:157), analisis deskriptif diawali dengan pengkategorian data menurut aspek dan sub aspek. Selanjutnya dilakukan interpretasi dengan menggunakan analisis isi, naratif, dan semiotika seperti yang diungkapkan oleh Denzin (2009:498). Analisis isi harus dilanjutkan dengan analisis semiotik karena analisis isi hanya mampu menganalisis secara intrinsik saja. Analisis naratif yang dimaksud dalam penelitian ini bukan analisis naratif yang bersifat formalistik, namun bersifat simbolik. Analisis ini melihat teks sastra sebagai tindak simbolik atau sarana untuk membingkai, mendifinisikan, dan memaknai sebuah situasi sekaligus memungkinkannya untuk diberi respon.

Analisis secara keseluruhan dalam penelitian ini menggunakan teori New Historisism. Melalui cara pandang New Historisism akan dilakukan penafsiran terhadap kekerasan yang menimpa perempuan, yakni perdagangan perempuan. Ada kaitan yang erat antara kekerasan terhadap perempuan, khususnya perdagangan perempuan dengan sejarah yang ikut membentuk terciptanya karya sastra. Ada timbal balik antara keduanya. Dalam rangka melihat kaitan antara sejarah dan sastra dalam cara pandang New Historicisms ini digunakan konsep-konsep dan praktik sosial, yang merupakan konteks sejarah, yang berkaitan erat dengan fokus penelitian, yakni kekerasan, patriarkhi, dan feminisme. Nilai yang dipegang oleh peneliti dalam New Historicism sangat menentukan hasil penafsiran. Nilai yang dipegang peneliti adalah nilai feminisme yang sesuai dengan budaya Jawa.

\section{HASIL DAN PEMBAHASAN}

Pada bagian ini akan diuraikan praktik sosial perdagangan perempuan, pemahaman sosial yang melatari terjadinya perdagangan perempuan, dan ideologi yang didukung oleh fiksi Jawa modern bertema perdagangan perempuan. Ketiga hal tersebut merupakan bagian dari enam permasalahan yang dikemukakan oleh Greenblatt. Ketiga hal tersebut mengarah pada permasalahan bagaimana sejarah sosio budaya membentuk teks sastra Jawa modern bertema perdagangan perempuan.

\section{Praktik Sosial Perdagangan Perempuan dalam Fiksi Jawa Modern}

Unsur-unsur perdagangan perempuan tampak dalam novel Astirin Mbalela. Tokoh Astrin direkrut dan ditipu oleh seorang calo laki-laki perdagangan perempuan bernama Johan Nur. Dengan dalih akan diberi pekerjaan, Astirin dijual kepada Bos sindikat perdagangan perempuanseperti dalam cuplikan di bawah ini.

"Ah, sing bener! Endi ana pabrik blek ing Nunukan! Kowe diapusi ngono kuwi jenenge. Nunukan kuwi pulau sepi, mung gegrumbulan thok. Wong sing mrono adate wong slundupan, dislundupake menyang Tawao, laladan Malaysia... Yen wis mlebu menyang Malaysia, dianggep buron. Didagangake dening para penadah. Didadekake pelayan bar ing kutha-kutha Malaysia alias wong pelanyahan" (Brata, 2007:97).

Artinya:

"Ah, yang benar! Mana ada pabrik blek di Nunukan! Kamu ditipu. Nunukan itu pulau sepi, hanya ada tanaman perdu dan semak-semak. Orang yang ke sana biasanya slundupan, diselundupkan ke Tawao, wilayah Malaysia... Kalau sudah masuk wilayah Malaysia, dianggap buron. Diperdagangkan oleh para penadah. Dijadikan pelayan bar di kota-kota Malaysia alias pelacur" (Brata, 2007:97).

Kutipan di atas menunjukkan adanya aktivitas perdagangan perempuan. Ketiga 
aspek yang menandai adanya perdagangan perempuan dalam cerita karya Suparto Brata itu tampak jelas. Astirin dan sepuluh perempuan muda ditipu oleh sebuah sindikat, yang diketuai oleh tokoh bernama Pak Bas, akan diberi pekerjaan di pabrik blek. Kenyataannya mereka dijual ke Tawao, untuk diperdagangkan sebagai perempuan penghibur, bukan dipekerjakan di Nunukan. Para perempuan mendapat kekerasan fisik dan seksual. Mereka juga mengalami kekerasan psikologis. Mereka akan kehilangan kebebasan, karena mereka dikejar-kejar oleh polisi Malaysia karena statusnya yang tidak jelas. Kehilangan kebebasan dan bekerja di bawah paksaan merupakan aspek ketiga perdagangan orang.

Praktik perdagangan perempuan membentuk cerita karya Suparto Brata berjudul Astirin Mbalela. Sejarah perdagangan perempuan menurut Susanto (2008) mencuat di Indonsia tahun 1993. Modus tindak kejahatanperdagangan orang sangat beragam, mulai dari dijanjikan pekerjaan, penculikan korban, menolong wanita yang melahirkan, penyelundupan bayi, hingga memperkerjakan sebagai PSK. Umumnya para korban baru menyadari bahwa dirinya merupakan korban perdagangan perempuan setelah tidak mendapatkan perlakuan yang tidak manusiawi, alias dieksploitasi. Eksploitasi seksual merupakan kasus yang paling banyak terjadi pada perdagangan perempuan.

Novel Astirin Mbalela telah ditulis berupa cerita bersambung tahun 1992, menjelang kasus perdagangan perempuan mencapai puncaknya. Hingga tahun 2006 data perdagangan perempuan yang dicatat oleh Wardani (2006), untuk wilayah Tulungagung, korban perdagangan perempuan menempati peringkat tiga, setelah Malang dan Bangkalan. Menurut catatan LSM Samitra Abhaya (Tejo, 2007), perdagangan perempuan menduduki peringkat pertama kekerasan di Jawa Timur, yakni $50 \%$, sedangkan permasalahan yang bisa ditangani sangat kecil. Menurut laporan Birohumas Propinsi Jawa Timur (Putra, 2009) kasus yang bisa ditangani tidak ada $10 \%$. Kecilnya keberhasilan penanganan kasus tersebut dikarenakan kurangnya koordinasi dengan daerah dan lembaga-lembaga lain.

Dua cerita ini memaparkan adanya perdagangan perempuan di dalam negeri. Dua tokoh perempuan muda dalam dua cerita ini ditipu dan dipaksa bekerja sebagai perempuan penghibur oleh sebuah sindikat pelacuran. Mereka ditipu, disekap, diancam, dan dieksploitasi.

Modus operandi perdagangan perempuan dalam cerita Trah(2008) ini sama dengan yang terjadi pada novel Astirin Mbalela. Tokoh perempuan bernama Tilarsih ditipu oleh calo sindikat perdagangan perempuan. Tokoh cerita yang berperan sebagai calo perempuan bernama Atun menjajikan Tilarsih pekerjaan sebagai penyanyi di Jakarta. Kita perhatikan rayuan Atun kepada calon mangsanya dalam kutipan berikut ini.

"Sih, bareng bosku tak critani yen aku duwe bibit bidhuan sing bisa ngetop, katon ketarik banget. Mula kongkon supaya enggal bisa nggawa kowe nyambut gawe ing kafene. Dheweke butuh penyanyi berbakat. Upama neng kene isih ana kekurangane, bos saguh moles. Saguh mulang carane nembang ing panggung hiburan" (Danusubrata, 2008:36).

Artinya:

"Sih, setelah saya cerita kepada bos bahwa saya punya penyanyi ngetop, tampak tertarik sekali. Maka, ia menyuruh saya untuk membawamu bekerja di kafenya. Ia butuh penyanyi berbakat. Seandainya di sini masih ada kekurangan, bos sanggup memoles. Sanggup mengajar cara menyanyi di panggung hiburan"(Danusubrata, 2008:36). 
Tokoh Tilarsih diiming-iming pekerjaan sebagai penyanyi di Jakarta. Tokoh perempuan tersebut sangat semangat menerima tawaran dari calo perempuan bernama Atun, karena menjadi penyanyi merupakan cita-citanya. Tawaran tersebut diterimanya dengan gembira dan penuh harapan karena akan ada orang yang mau membimbing mencapai cita-citanya secara profesional.

Tokoh utama bernama Lely dalam cerita Mecaki Lurung kang Ilang karya Ismoe Rianto (2008) juga merupakan korban perdagangan perempuan. Perempuan yang dikhianati oleh suaminya tersebut menjadi perempuan penghibur karena ditipu oleh calo sebuah kompleks pelacuran. Cuplikan berikut ini menjelaskan asal mula Lely menjadi perempuan penghibur.

Sabanjure Lely crita yen Jarot kuwi gaweyane pancen golek wong wadon. Lely dhewe sing sekawit pengin dadi TKW, disanggupi Jarot. Jarot ngajak mendemmendeman. Lely dipeksa melu ngincipi, nganti sirahe mumet. Wusanane ora eling apa-apa. Nalika nglilir awake remuk rempu. Sing gawe kaget malah wis ora nganggo apa-apa maneh... (Rianto, 2008:21).

Artinya:

Selanjutnya Lely cerita kalau Jarot memang bekerja sebagai pencari mangsa perempuan. Lely yang semula ingin menjadi TKW, disanggupinya. Jarot mengajak minum minuman keras. Lely dipaksa ikut menenggak minuman keras, sampai kepalanya pusing. Akhirnya tidak ingat apa-apa. Ketika terbangun, badannya terasa sakit. Yang mengejutkan, ia sudah tidak berbaju ...(Rianto, 2008:21).

Terbukti bahwa Jarot seorang calo perdagangan perempuan. Calo perdagangan perempuan punya cara khas dalam menjerat mangsanya. Jarot menipu mangsanya dengan dalih memberi pekerjaan. Setelah perempuan yang menjadi mangsanya percaya, perempuan tersebut diberi minuman keras. Setelah mabuk perempuan tersebut diumpankan kepada lelaki hidung belang.

Ada perubahan status perempuan korban perdagangan. Penelitian Wismayanti (2010:76) menyatakan bahwa telah terjadi perubahan status bagi perempuan korban perdagangan, setelah melalui proses pembiasaan mereka berubah status menjadi melacurkan diri. Tahap tersebut terjadi juga pada tiga perempuan korban perdagangan tersebut. Astirin yang telah diperkosa lebih dahulu oleh Johan Nur, calo yang menjualnya, sudah tidak ragu lagi untuk menceburkan diri ke dunia hitam di Bontang (Brata, 2007:146). Tokoh Tilarsih, setelah bosnya ditangkap polisi, ia juga terpaksa melacurkan diri untuk mempertahankan hidup di Jakarta (Danusubrata, 2008:117).

\section{Pemahaman Sosial yang Melatari Ter- jadinya Perdagangan Perempuan dalam Fiksi Jawa Modern}

Pemahaman sosial yang melatari terjadinya perdagangan perempuan merupakan penyebab terjadinya kekerasan perdagangan perempuan. Hal tersebut akan dilihat dari pandangan masyarakat yakni laki-laki terhadap perempuan. Di samping itu, peran yang dilekatkan dan dimainkan perempuan dalam masyarakat juga berpengaruh terhadap kekerasan yang menimpa perempuan. Ketiga, pendidikan dan kemiskinan juga menjadi pemicu bagi perempuan untuk terjebak dalam berbagai praktik yang mengandung kekerasan.

Kajian dimulai dari teks dikaitkan dengan sejarah tentang titik tolak masyarakat dalam memandang perempuan. Titik tolak pandangan masyarakat yang dimaksud adalah hegemoni patriarkhi. Konsep tersebut telah dianut oleh masyarakat Jawa sejak lama. Laki-laki sebagai ayah memiliki peran dominan dalam ranah ru- 
mah tangga maupun masyarakat (Irianto, 2006:395).

Pandangan rendah laki-laki terhadap perempuan merupakan salah satu kemungkinan yang muncul dari sistem patriarkhi. Pandangan rendah laki-laki terhadap perempuan tersebut tidak selalu diungkapkan dengan kata-kata. Sebagian besar pandangan tersebut tercermin pada sikap dan perilaku mereka dalam interaksinya dengan perempuan. Pandangan rendah tersebut tampak pada anggapannya terhadap perempuan sebagai objek seks, barang komoditi, mesin produksi, dan kelompok minoritas dalam keluarga.

Tokoh calo dalam ketiga cerita di atas memiliki pandangan perempuan sebagai barang komoditi yang mendatangkan uang. Kedua laki-laki yang berperan sebagai calo dalam cerita Mecaki Lurung kang Ilang (2008) karya Ismoe Riyanto dan Astirin Mbalela (2007) karya Suparto Brata, menjebak kedua tokoh perempuan dalam cerita tersebut untuk dijadikan barang komoditi, dijual dengan cara dilacurkan.

Laki-laki calo bernama Jarot dalam cerita Mecaki Lurung kang Ilang, memandang perempuan sebagai barang komuditi, dijual dan menghasilkan uang. Kita perhatikan kutipan berikut ini.

Rumangsa wis ora kuwat ana ngomah, Lely minggat. Jroning kahanan bingung lan putus asa, ing terminal ketemu Jarot... Jarot iku tukang golek mangsa. Lan ing dina-dina sabanjure ora mung kancane Jarot sing teka lan kudu diladeni. Jangkep sewulan banjur diboyong menyang wisma Dahlia ... (Rianto, 2008:22).

Artinya:

Merasa sudah tidak betah di rumah, Lely pergi dari rumah. Dalam keadaan bingung dan putus asa, di terminal bertemu dengan Jarot... Jarot ternyata tukang mncari mangsa. Di hari-hari selanjutnya, tidak hanya teman Jarot saja yang harus dilayani. Setelah satu bulan, Lely diboyong ke wisma Dahlia ... (Rianto, 2008:22).
Jarot yang dari awalnya menolong Lely, ternyata justru menjebak. Perilaku Jarot tersebut menggambarkan pandangannya terhadap perempuan. Bagi Jarot perempuan merupakan barang dagangan yang mendatangkan uang. Terbukti sikap baik Jarot di awal ketika bertemu dan menolong Lely hanya merupakan taktik saja untuk menjebak Lely. Perempuan dibuat percaya dan merasa berhutang kebaikan, sehingga mudah diperdaya. Selain menganggap perempuan sebagai barang dagangan, dari perilaku tokoh Jarot yang berprofesi sebagai calo tersebut juga tergambar anggapan terhadap perempuan sebagai objek seks. Perempuan dijadikan pelacur, objek seks. Perempuan sebagai pemuas nafsu laki-laki. Lely yang sudah berhasil dijebak dan diceburkan ke dunia pelacuran selanjutnya dipindahkan ke wisma Dahlia, sebuah kompleks pelacuran resmi.

Pandangan rendah terhadap perempuan tidak selalu datang dari musuh maupun orang luar, namun bisa datang dari kerabat bahkan orang yang sudah dianggap sebagai orang tua. Tokoh Pakdhe Mar misalnya, paman yang sudah dianggap Astirin sebagai orang tua. Paman tersebut yang sudah membesarkan Astirin. Kita perhatian cuplikan berikut ini.

"Lho, aku isih sekolah," mak clemong Astirin mucap,...

"Alaa, sekolah ki sing kokgoleki ya apa, wong sidane kowe ya kawin!" Buamin ngomonge rada kasar.

"Iya, kok, Rin... Kena apa mesthi ditutug-tutugake, yen ana dalan nyidhat kang luwih gampang nglakoni urip?"... (Brata, 2007:20).

Artinya:

"Lho, aku masih sekolah" Astirin menyela begitu saja,...

"Alaa, untuk apa sekolah?Apa yang dicari? Akhirnya kamu nanti juga menikah!"Buamin bicara dengan nada kasar. 
“Ya, Rin... Untuk apa harus diselesaikan? Kalau ada jalan pintas, kenapa tidak?" (Brata, 2007:20).

Dialog di atas merupakan pembicaraan antara tokoh Pakdhe Mar, Astirin, dan Buamin dengan sudut pandang orang ketiga. Pakdhe Mar dan Buamin, lelaki yang akan menikahi Astirin, memiliki pandangan yang rendah terhadap perempuan. Perempuan tidak perlu sekolah tinggi. Putus asa karena dihentikan keinginannya untuk belajar dan akan dikawinkan menyebabkan tokoh Astirin pergi dari rumah, diperkosa dan dijual oleh calo perdagangan perempuan bernama Johan Nur (Brata, 2007:96).

Pandangan rendah terhadap perempuan dalam novel Trah juga dapat dilihat dari perilaku laki-laki bernama Kacuk. Laki-laki tersebut memandang Tilarsih sebagai objek seks. Setengah memaksa, laki-laki tersebut mengajak Tilarsih kencan seperti dalam cuplikan berikut ini.

"Aku wis suwe kepingin banget kencan karo kowe... aku mung kepingin kencan karo kowe... nggolek losmen... nginep pirang dina, dadi le dolan isa puas... aku sir nek weruh kowe, kejaba kuwi uga wis ngerti pegaweyanmu."

Krungu tembunge Kacuk, Tilarsih krasa lara banget atine (Subrata, 2008:25).

Artinya:

"Saya sudah lama ingin sekali kencan denganmu... saya hanya ingin kencan dengan kamu... mencari losmen saja... menginap beberapa hari begitu, biar bisa puas... saya naksir sekali sama kamu, selain itu saya sudah tahu pekerjaanmu."

Mendengar kata-kata Kacuk, Tilarsih merasakan sakit hati yang amat sangat (Subrata, 2008:25-6).

Pandangan rendah laki-laki tersebut dapat dilihat dari perilakunya yang kasar dan rayuan seksnya kepada Tilarsih. Ada unsur paksaan yang dipadu dengan perlakuan kasar, sehingga menimbulkan rasa takut pada Tilarsih. Pandangan rendah tersebut menimbulkan kekerasan psikologis. Ada sakit hati yang amat sangat di hati Tilarsih menerima rayuan dan perlakuan kasar tersebut.

Kebergantungan perempuan menjadi faktor kedua yang melatari terjadinya kekerasan terhadap perempuan, khususnya perdagangan perempuan. Ada dua kelompok peran yang melekat pada diri perempuan, yakni peran perempuan tradisional dan perempuan mandiri (Ferguson, 1981:6-11). Perempuan tradisional adalah perempuan yang hidupnya bergantung kepada orang lain. Sedangkan perempuan mandiri adalah perempuan yang tidak bergantung kepada siapapun dan dapat mencukupi kebutuhannya. Kebergantungan perempuan kepada orang lain menyebabkan mereka riskan terkena kekerasan. Namun tidak semua perempuan yang memiliki sifat kebergantungan mendapatkan kekerasan. Terjadinya kekerasan bergantung kepada sikap laki-laki. Kekerasan sebagian besar terjadi karena laki-laki tidak menghargai perempuan.

Tokoh perempuan dalam ketiga cerita yang diteliti ini pada awalnya menunjukkan peran perempuan tradisional yang menggantungkan hidupnya kepada orang lain. Sebagai istri mereka bergantung kepada suami. Sebagai anak, mereka bergantung kepada orang tua.

Sifat kebergantungan hidup perempuan kepada suami dalam cerita Mecaki Lurung kang Ilang (2008) menyebabkan tokoh perempuan terjebak pada pekerjaan sebagai penjaja seks, seperti dalam cuplikan di bawah ini.

Yen dipikir, apa ta kurange Lely kuwi? Ayu, lencir, kuning, resik. Andhap asor, kumraket karo kanca. Bekti nyang bojo...

...ing terminal ketemu karo Jarot sing banjur nggawa Lely dipasrahake marang wong wadon sing diundang tante. Nganti 
patang ndina manggon ing omahe wong wadon sing durung ditepungi kuwi ... (Rianto, 2008:22).

Artinya:

Kalau dipikir, apa yang kurang pada diri Lely? Cantik, langsing, kuning, bersih. Sopan santun, akrab dengan teman. Berbakti kepada suami...

...di terminal bertemu dengan Jarot yang kemudian membawa dan menyerahkan Lely kepada seorang perempuan yang dipanggil tante. Sampai empat hari ia bermalam di rumah perempuan yang belum dikenalnya itu ... (Rianto, 2008:22).

Narasi di atas memberi penjelasan bahwa tokoh utama yang bernama Lely dalam cerita tersebut merupakan perempuan bergantung. Meskipun cantik dan sopan, ia hanya seorang istri yang menggantungkan hidupnya kepada suami yang akhirnya ditinggal selingkuh. Sifat kebergantungannya mengakibatkan ia tidak bisa mandiri setelah ditinggal selingkuh oleh suaminya. Peran perempuan tradisional tersebut membiasakannya bergantung kepada orang lain. Begitu ia mencoba keluar dari rumah, ia justru menjadi mangsa calo perdagangan perempuan seperti Jarot. Sebagai orang yang menumpang perempuan tersebut juga tidak merasa risih meskipun sudah menginap empat hari. Sifat kebergantungannya membuatnya tidak peka terhadap bahaya yang mengancamnya, karena ia biasa bergantung kepada suaminya.

Dua tokoh perempuan lainnya dari novel Trah dan Astirin Mbalela juga merupakan perempuan muda yang bergantung kepada orang tuanya. Tokoh Tilarsih dalam Trah merupakan gadis muda yang masih ikut neneknya (Subrata, 2008:57). Tokoh Astirin dalam Astirin Mbalela merupakan gadis muda yang masih sekolah di bangku SMP (Brata, 2007:23).
Kemiskinan merupakan faktor ketiga terjadinya kekerasan perdagangan perempuan dalam ketiga cerita dalam penelitian ini. Di samping miskin, mereka juga berpendidikan rendah. Kemiskinan dan pendidikan yang rendah menjadikan mereka mudah ditipu dalam mencari pekerjaan. Berikut ini kondisi tokoh Astirin dalam Astirin Mbalela (2007).

"Iya, kok, Rin. Wong kowe sekolah anggonku mbayari SPP ya kanthi rekasa..."

Wis, kudu ora susah eman karo sekolahe! Marga upama ora mbalela saka karepe Pakdhe-Mbokdhe ya meksa kudu nyopot saka sekolah!(Brata, 2007.20-25).

Artinya:

"Ya, Rin. Saya membayar SPPmu juga susah..."

Sudah seharusnya tidak perlu menyesal tidak sekolah! Karena, seandainya tidak berontak dari PakdheMbokdhe, ya terpaksa harus putus sekolah! (Brata, 2007.20-25).

Tokoh Astirin disekolahkan oleh pamannya yang hidup sengsara. Perempuan muda tersebut harus putus sekolah, tidak dapat lulus SMP, karena pamannya bermaksud menikahkannya dengan lelaki kaya.

Kondisi serupa juga dialami oleh tokoh Tilarsih dalam cerita Trah (2008). Cuplikan berikut ini menjelaskan kondisi ekonomi tokoh tersebut.

Putune mung bisa tamat SMP banjur nganggur, lan neng ngomah supaya ngancani mbahne...(Danusubrata, 2008:68)

Tilarsih dilairake ana ing keluwarga miskin... Mbah Mardiyah kelingan kandhane Atun, wong sing nalika semana nggawa putune..."Mbah, dados penyanyi teng kutha niku kasile ageng sanget. Cobi nek dados penyanyi teng ngriki, sedalu pikantuk pinten?" (Danusubrata, 2008:36). 
Artinya:

Cucunya hanya bisa lulus SMP lalu tidak bekerja, dan di rumah hanya menemani neneknya...

Tilarsih lahir di tengah keluarga miskin...

Mbah Mardiyah teringat Atun, orang yang saat itu membawa cucunya..."Nek, menjadi penyanyi di kota besar itu hasilnya besar sekali. Coba, kalau menjadi penyanyi di sini semalam dapat berapa?"

Secara analitik pengarang menjelaskan kondisi kehidupan tokoh Tilarsih. Perempuan tersebut berasal dari keluarga miskin dan berpendidikan rendah.

\section{Ideologi yang Didukung Teks Fiksi Ber- tema Perdagangan Perempuan}

Setelah ideologi patriarkhi berakar kuat dalam tatanan hidup bermasyarakat dan menimbulkan berbagai kekerasan terhadap perempuan, sejarah mencatat munculnya gerakan perempuan yang memprotes dominasi dan kesewenangan laki-laki dalam sebuah gerakan feminisme (Saptari, 1997:48). Ideologi feminisme yang memiliki tuntutan persamaan hak antara laki-laki dan perempuan juga diterapkan di Indonesia, di Jawa khususnya. Melalui lembaga Pemberdayaan Perempuan, pemerintah berusaha menyiarkan ideologi feminisme yang disesuaikan dengan sosio budaya masyarakat Jawa yang masih akar kuat terhadap patriarkhi. Pemberian kesempatan yang sama terhadap hak lakilaki dan perempuan dalam segala bidang dan dorongan kepada perempuan untuk bekerja sehingga berdaya dilakukan pemerintah untuk mengangkat harkat dan martabat perempuan. Lahirnya UU KDRT merupakan keseriusan pemerintah dalam mengatasi kasus-kasus kekerasan yang menimpa perempuan dalam keluarga. Di samping mengatasi kekerasan, UU tersebut juga membatasi dan mengurangi kekerasan dalam rumah tangga.
Ideologi feminisme tampak membentuk sebagian besar tesk fiksi Jawa modern bertema perdagangan perempuan. Ketiga tokoh perempuan korban perdagangan perempuan dapat bangkit dan keluar dari kompleks pelacuran. Ideologi feminisme juga didukung oleh tokoh laki-laki. Astirin dalam Astirin Mbalela (2008) dapat lepas dari sindikat Pak Bas yang akan mengirimnya ke Malaysia dan dapat hidup mandiri seperti dalam kutipan di bawah ini.

"Aku ora bisa ngeterake kowe mudhun. Iki aku mung bisa bathon ngumpulake dhuwit kanggo sangu sajrone kowe golek pegawean sedina rong dina ing Bontang mengko.Cobanen dhisik. Dene yen wis katog kowe ora bisa urip, isih bisa nyegat ferry iki, nemoni aku utawa Sahudin..." (Brata, 2007:134-135).

Artinya:

"Saya tidak bisa mengantar kamu turun. Ini saya hanya bisa iuran uang dengan Sahudin untuk bekal kamu selama mencari pekerjaan barang sehari atau dua hari di Bontang. Coba dulu. Kalau sudah mentog tetap tidak bisa hidup, kamu masih bisa mencari ferry ini, menemui saya atau Sahudin ..."

Dukungan terhadap feminisme juga diberikan oleh tokoh laki-laki. Lelaki dalam cuplikan tersebut membantu Astirin lepas dari kekerasan perdagangan perempuan dan memberinya modal untuk hidup mandiri di Bontang.

Tilarsih dalam Trah (2008) juga bisa lepas dari kekerasan perdagangan perempuan. Keluarnya Tilarsh dari dunia hitam juga dibantu oleh tokoh laki-laki bernama Bagus seperti dalam kutipan di bawah ini. "...aku nekad nggoleki awakmu supaya gelem bali mlaku neng dalan urip sing bener." ... Arang banget wong lanang sing gelem ngregani wong wadon sing nasibe kaya Tilarsih.

"Mula yen sesuk trima urip lumrah lan sing pokok gelem nyelengi... Tansaya 
nek anggonmu bukak modiste bisa lancar" (Subrata, 2008:257).

Artinya:

“... saya nekat mencari kamu agar mau kembali ke jalan hidup yang benar." ...Jarang sekali laki-laki yang mau menghargai perempuan yang nasibnya seperti Tilarsih.

"Maka kalau nanti mau hidup sederhana dan yang penting mau menabung... Apalagi kalau usaha modistmu bisa berjalan lancar" (Subrata, 2008:257).

Ucapan tokoh Bagus di atas menggambarkan penghargaan dan kepeduliannya terhadap perempuan bekas penghibur.Tokoh Bagus juga merupakan laki-laki yang mendorong perempuan untuk mandiri. Hidup sederhana yang ditawarkan Bagus kepada Tilarsih adalah salah satu perwujudan pemikiran yang tidak mendorong perempuan hidup foya-foya menghamburkan uang suami. Pemikiran kedua tokoh Bagus yang mendukung feminisme terletak pada akhir dialog di atas yang mengharapkan usaha modist Tilarsih berkembang lancar. Harapan seperti itu pasti keluar dari diri lelaki yang mengizinkan dan menghargai perempuan untuk bekerja.

Tokoh Lely dalam Mecaki Lurung kang Ilang (2008) dapat keluar dari kompleks dunia hiburan dan hidup mandiri. Lely ini mempunyai niat yang bulat untuk meninggalkan perannya sebagai perempuan objek seks seperti dalam cuplikan di bawah ini.

Tekade wis gilig, arep bali mecaki dalan panguripan sing bener kanthi awak sing resik.

Mula, sadurunge patang sasi kudu duwe gawean kang gumathok. Yen wektu lodhang, Lely uga nggethu njait. Sawise rong ndina, dhaster cacah wolu katon dipajang, melu-melu ngrenggani kiose (Rianto, 2008:23).

\begin{abstract}
Artinya:
Tekatnya sudah bulat, akan kembali ke jalan yang benar dengan badan yang bersih.

Maka sebelum empat bulan harus sudah mempunyai pekerjaan yang pasti. Di waktu longgar, Lely juga rajin menjahit.Setelah dua hari, delapan daster sudah dipajang, ikut meramaikan kiosnya.
\end{abstract}

Tokoh Lely yang sudah tercebur dalam kenistaan dengan menjadi wanita tuna susila mempunyai tekat untuk kembali ke masyarakat. Lely membuktikan niatnya tersebut dengan menjual semua perhiasan yang diperolehnya untuk modal usaha. Selain membebaskan diri dari peran objek seks, Lely juga berusaha untuk mandiri. Dengan sedikit modal yang ada perempuan tersebut menyewa sebuah rumah untuk membuka toko dan jasa jahitan.

Dukungan terhadap ideologi feminisme dalam fiksi Jawa modern sangat memperhatikan sosio budaya masyarakat Jawa. Kemandirian perempuan tidak diikuti oleh tindakan-tindakan radikal seperti yang dilakukan oleh feminisme radikal. Para perempuan mandiri dalam fiksi Jawa modern merupakan perempuan-perempuan yang masih bisa dan ingin hidup berdampingan dengan lelaki, saling mengisi dan bahu membahu. Ketiga tokoh korban perdagangan perempuan semuanya bekerja sama dengan laki-laki untuk lepas dari cengkeraman calo. Tokoh Astirin dalam Astirin Mbalela mendapat bantuan dari Sahuddin untuk lolos dari tipuan calo perdagaangan perempuan. Lely dalam Mecaki Lurung kang Ilang mendapat kekuatan dari Rasmoyo sehingga bertekat lepas dari kungkungan calo pelacuran. Tilarsih dalam Trah mendapat dukungan dan kekuatan dari bagus untuk lepas dari dunia pelacuran. Demikian juga, laki-laki bersikap menghargai perempuan, tidak melakukan 
kekerasan, sebaliknya memberi bantuan kepada perempuan lepas dari kekerasan dan membantu perempuan untuk mandiri. Hal tersebut tampak dalam sikap penutur yang tertuang dalam penyelesaian cerita. Dua cerita dari tiga cerita yang mendukung ideologi feminisme diakhiri dengan bertemu jodoh atau menikahnya pasangan tokoh muda-mudi. Tilarsih dan Lely menikah dengan pasangannya di akhir cerita.

\section{SIMPULAN}

Praktik sosial perdagangan perempuan membentuk tema kekerasan terhadap perempuan dalam fiksi Jawa modern yang terbit tahun 2005-2010. Modus operandi para calo dan sindikat perdagangan perempuan yang tumbuh subur di Jawa mulai tahun 1993 tergambar dalam tiga cerita fiksi Jawa modern, seperti Astirin Mbalela (2007), Mecaki Lurung kang Ilang (2008), dan Trah (2008). Hegemoni patriarkhi terhadap perempuan yang dicatat dalam sejarah telah bercokol berpuluh-puluh abad lamanya dalam tatanan kehidupan berumah tangga dan bermasyarakat di negara kita, di Jawa khususnya. Tatanan kehidupan tersebut yang meletakkan perempuan sebagai pihak yang inferior dan mendudukan perempuan sebagai perempuan bergantung, memicu laki-laki memandang rendah perempuan dan bertindak sewenang-wenang. Hal itulah yang merupakan pemahaman sosial yang menjadi penyebab utama terjadinya kekerasan terhadap perempuan, salah satunya perdagangan perempuan. Pandangan rendah laki-laki terhadap perempuan terdapat dalam tiga cerita fiksi Jawa modern yang menjadi sumber data penelitian ini. Para tokoh perempuan dipandang rendah, dianggap sebagai objek seks, sehingga dijual sebagai perempuan penghibur. Kemiskinan dan pendidikan yang rendah dari perempuan juga menjadi penyebab perempuan dijual. Perempuan miskin dan berpendidikan rendah mudah diperdaya dalam mencari pekerjaan, hingga dijual sebagai perempuan penghibur. Ideologi feminisme didukung oleh teks fiksi Jawa modern bertema perdagangan perempuan ini. Tiga tokoh perempuan dalam teks fiksi bertema perdagangan perempuan ini semuanya bisa lepas dari kekerasan perdagangan perempuan. Mereka bisa kembali ke masyarakat dan dapat hidup mandiri. Pengaruh ideologi tersebut sebagai pembentuk cerita fiksi Jawa modern diperkuat dengan waktu penerbitan ketiga karya tersebut setelah tahun 2004, setelah UU KDRT lahir.

Feminisme yang didukung oleh teks fiksi Jawa modern bertema perdagangan perempuan ini sesuai dengan budaya Jawa. Tiga tokoh perempuan korban perdagangan perempuan tersebut hidup berdampingan dengan laki-laki. Bahkan tokoh laki-laki memberikan bantuan kepada perempuan untuk lepas dari kekerasan perdagangan perempuan dan juga membantu mereka untuk mandiri. Para tokoh perempuan juga menemukan pasangan hidupnya di akhir cerita.

\section{UCAPAN TERIMA KASIH}

Saya mengucapkan terima kasih kepada kedua pembimbing saya, yaitu Prof. Dr. Haris Supratno dan Prof. Dr. Fabiola Kurnia Darmawati, M.Pd. yang telah memberikan bimbingan sehingga penelitian ini terselesaikan dengan hasil yang baik. Ucapan terima kasih juga saya sampaikan kepada Prof. Dr. Budi Darma, Dra. Sri Kusumo Habsari, Ph.D., dan Prof. Dr. Setya Yuwana Sudikan, Dr. Hartono, dan Prof. Ketut Budayasa, Ph.D. yang telah memberikan masukan-masukan yang sangat berharga untuk memperbaiki penelitian ini.

\section{DAFTAR PUSTAKA}

Aminuddin. 1996. "Metode Kualitatif dalam Penelitian Karya Sastra" dalam Aminuddin. Pengembangan Penelitian 
Kualitatif dalam bidang Bahasa dan Sastra. Malang: Yayasan 3 A.

Budianta, Melani. “Budaya, Sejarah, dan Pasar: New Historicism dalam Perkembangan Kritik Sastra" dalam jurnal Susastra Vol 2 Nomor 3, hal 1-19. Jakarta: HISKI.

Brannigan, John. 1999. "'Introduction: History, Power and Politics in Literary Artifact" in in Julian Wolfreys (ed.). Literary Theories. New York: New York University Press.

Brata, Suparto. 2007. Astirin Mbalela. Yogyakarta: Narasi.

Con, Robert dan Ronald Schleifer. 1989. Contemporary Literary: Literary and Cultur Study. New York: Longman.

Damono, Sapardi Djoko. 1979. Sosiologi Sastra Sebuah Pengantar. Jakarta: Balai Bahasa.

Danusubroto, Atas. 2008. Trah. Yogyakarta: Narasi.

Darma, Budi. 2007. Bahasa, Sastra, dan Budi Darma. Surabaya: JP Books.

Denzin, Norman K. 2009. Handbook of Qualitative Research.Terjemahan Dariyatno, dkk. Yogyakarta: Pustaka Pelajar.

Ferguson, Mary Anne. 1981. Images of Women in Literature. London: Palo Alto.

Greenblatt, Stephen and Catherine Gallagher. 2000. Practicing New Historicism. Chicago: The University of Chicago Press.

Greenblatt, Stephen. 2005. Renaissance SelfFashioning. Chicago: The University of Chicago Press.

Hassan, Tholchah. 2004. “Kata pengantar Paradigma Gender"' dalam Mufidah. Paradigma Gender. Malang: Bayumedia.

Herkiswono, Harkristuti. 2000. “Perempuan dan Hak Azasi Manusia dalam Perpektif Yuridis". Dalam Negara dan Kekerasan terhadap Perempuan. Yakarta: Yayasan Jurnal Perempuan.

Irianto, Sulistyowati. 2000. “Diskusi mengenai Bentu-bentuk Kekerasan terhadap Perempuan dan Alternatif Pemecahannya (Suatu Tinjauan Hukum)". Dalam AchieSudiarti Luhumina (ed). Pemahaman Bentuk-Bentuk Tindak Kekerasan terhadap Perempuan dan Alternatif Pemecahannya. Jakarta: Pusat Kajian Wanita dan Gender UI.

Myers, G.D. "The New Historicism in Literature" dalam http://wwwenglish.tamu.edu/pers/fac/myers/ newhistoricism.html. Diakses tanggal 25-12-2009.

Riyanto, Ismoe. 2008. Mecaki Lurung kang Ilang. Surabaya. Penerbit Jaya Baya.

Saptari, Ratna dan Brigitte Holzner. 1997. Perempuan Kerja dan Perubahan Sosial. Jakarta: Grafiti Press.

Sunarto. 2001. Metode Penelitian Ilmu-ilmu Sosial dan Pendidikan. Surabaya: Unesa University Press.

Swingewood, Alan dan Diana Laurenson. 1972. Sociologi of Literature. London: Paladin.

Tejo, Amir. 2007. “Kasus Trafficking Peringkat Pertama di Jatim" dalam Okezonehttp://news.okezone.com. Diakses tanggal 5 Januari 2011.

Tyson, Lois. 1999. Critical Theory Today: A User-Friendly Guide. New York: Garland Publishing Inc.

Wahyuningsih, Sri, dkk. 2003. Dagang Manusia: Kajian Trafficking terhadap Perempuan dan Anak. Yogyakarta: Lappera Pustaka Utama.

Wandita, Galuh. 2000. “Air Mata Telah Terkuras tetapi Kekerasan Belum Selesai". Dalam Negara dan Kekerasan terhadap Perempuan. Yakarta: Yayasan Jurnal Perempuan.

Wellek, Rene dan Austin Warren. 2001. Teori Kesusasteraan (Diindonesiakan oleh Melani Budianta). Jakarta: Gramedia.

Wismayanti, Yanuar Farida. 2010. “Dunia Kecil yang Kujalani: Jejak Anak Perempuan yang Dilacurkan di Kota Surabaya". Tesis. Pasca Sarjana UGM. Belum diterbitkan. 